\title{
Image Differentiation for Competitive Advantage in the Private Tertiary Education Institutions in Botswana
}

\author{
Douglas Chiguvi ${ }^{1 *}$, Ruramayi Tadu ${ }^{2}$
}

\begin{abstract}
${ }^{1}$ Senior Lecturer: Marketing Programmes, Entrepreneurship Department, BA ISAGO University P. Bag 149, Gaborone, BOTSWANA
${ }^{2}$ Vice President - Academic Affairs \& Research, BA ISAGO University, P. Bag 149, Gaborone, BOTSWANA

*Corresponding Author: dchiguvi@gmail.com
\end{abstract}

Citation: Chiguvi, D. and Tadu, R. (2020). Image Differentiation for Competitive Advantage in the Private Tertiary Education Institutions in Botswana. Dutch Journal of Finance and Management, 4(1), em0063. https://doi.org/10.29333/djfm/8401

\begin{tabular}{lll}
\hline ARTICLE INFO & $\begin{array}{l}\text { ABSTRACT } \\
\text { Received: 2 May 2020 }\end{array}$ & $\begin{array}{l}\text { The primary objective of the study was to describe the extent to which image differentiation strategies may be } \\
\text { used to gain competitive advantage among private tertiary education institutions in Botswana. The study } \\
\text { examined how image differentiation may be employed by private tertiary education institutions to achieve } \\
\text { competitive advantage. The study used descriptive survey research and the findings revealed that the institutions } \\
\text { have not done enough in image differentiation to clearly stand out as differentiated universities. The study } \\
\text { recommends that the universities must get involved in activities that will enhance institutions' image. } \\
\text { Institutions need to work together with key stakeholders and continually seek ways to attain competitive } \\
\text { advantage through image differentiation. }\end{array}$ \\
&
\end{tabular}

Keywords: image differentiation, competitive advantage, private tertiary institutions

\section{INTRODUCTION}

Private tertiary education institutions are wrestling with decisions of how to effectively compete in local and international markets, but the quality of the programmes is not appreciated by students and the industry at large. In this era of globalisation and tertiary education landscape becoming highly competitive, only those institutions that are competitive and differentiated are more likely to withstand the competitive pressures within the industry. Competitive advantage is defined as what makes a company better than its competitors in customer's minds (Amadeo, 2017). The aim of this research study is to describe image differentiation strategies tertiary education institutions may employ to achieve competitive advantage. According to Amadeo (2017) differentiation means the firm delivers better benefits than anyone else by providing a unique or high quality product, faster and in a way that reaches the customers better. Mateus (2017) noted that differentiation is more concerned with providing unique and innovative products, and should be regarded as going beyond product or service attributes to encompass everything that positively influence the value that customers derive from it. Mateus (2017) explained that differentiation creates customer experience as it serves as a bridge to engage customers. As tertiary education institutions face competition from around the globe, they must respond to the complex factors that have an impact on attracting and retaining customers. Mixon (2014) concluded that competitive advantage in tertiary education develops over time due to quality of graduates. He argued that if universities foster and remain in the fields in which they have competitive advantage, they will continue to recruit top students and maintain funding at an acceptable level. This study therefore seeks to explore how tertiary education institutions may gain competitive advantage though pursuance of image differentiation strategies.

\section{LITERATURE REVIEW}

\section{Overview of the Botswana Tertiary Education Sector}

The Botswana Tertiary Education sector has grown quite significantly over the past eight years (2010-2018). To-date, tertiary education in Botswana is provided by 35 registered (private and public) institutions and operates under the Tertiary Education framework, guided by the Ministry of Tertiary Education, Research, Science and Technology. According to NDP11 report, (2017) education is considered the most critical factor in Botswana's transformation to knowledge economy and society and has been a key priority development for the country receiving the highest budget. Botswana's Tertiary education is offered through a combination of public and private universities and colleges who offer various qualifications ranging from certificates, 


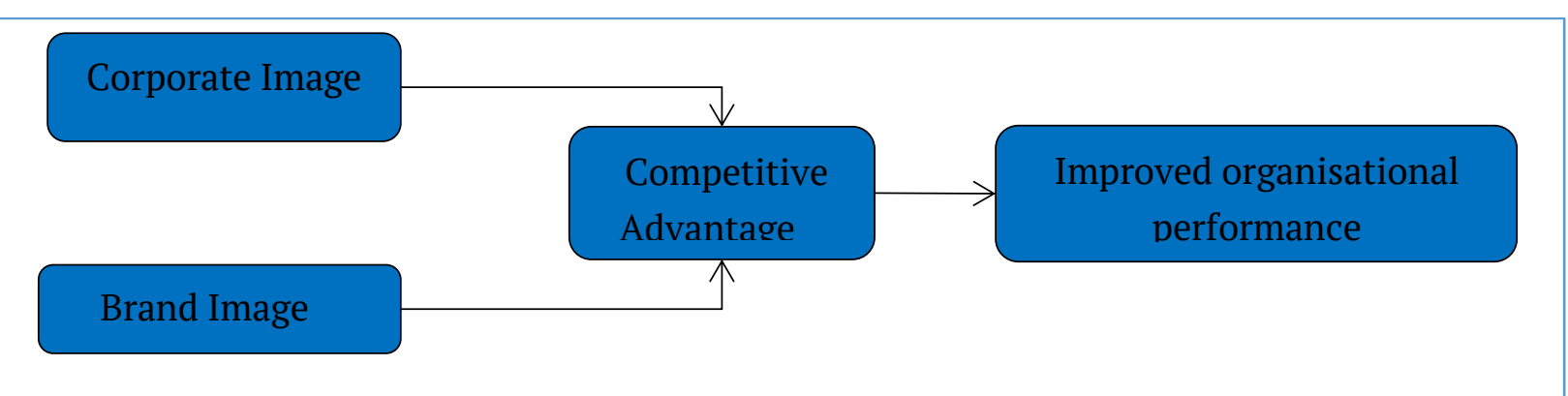

Figure 1. Corporate image, Brand Image and Competitive advantage

diploma, graduate and post graduate qualifications. Private sector education plays an integral part of the higher education landscape enrolling about $42.6 \%$ of students as compared to the $57.4 \%$ in public sector during 2014/2015 ( HRDC, 2015). The Botswana's tertiary education sector is highly regulated by two key institutions, namely the Botswana Qualifications Authority (BQA) and the Human Resource Development Council (HRDC). Boyd (2012) noted that given the struggling economies, tertiary education institutions are dealing with declining revenues and searching for ways to do more for less can be found through employment of unique strategies. He suggested that in order to achieve this, tertiary education institutions should place a reviewed focus on exceeding expectations and needs of their customers since students are seeking educational opportunities in institutions that meet their needs. To survive and remain competitive, private tertiary education institutions need to keep abreast, adapt to the competitive landscape and differentiate their institutions to attract both local and global students and satisfy industry and national needs. The purpose of differentiation is to create a product or service, which will differ from other products or services that are provided by the competitors (Zekiri and Nadelea, 2011). The tertiary education environment has become competitive and many public and private have begun to adopt market oriented strategies as a result (Leland and Moore, 2007). There is need for Botswana private tertiary education institutions to operate like any other consumer driven markets, introducing new demands and taking greater risks. Competition places great pressure on the business models of most colleges and universities. Over the past years 2015 to date, several institutions were faced with low or no enrolment in certain programmes and have relied on certain key segments or programme to sustain their business models. Universities have traditionally been product based organisations, with product providers (faculty and academics) having substantial power to determine product offerings (programmes, courses) and delivery methods. There is need to build institutions that clearly understand which consumers they are targeting, what those consumers need, and how they prefer to be serviced (Ernst and Young, 2011). The main challenge for tertiary education institution is to unleash strategies to set themselves apart from competition and increase competitiveness in the market in a bid to position themselves to stakeholders as a "university of choice".

\section{Image Differentiation}

According to Podnar (2015), images are perceptions or set of beliefs, attitudes and impressions of an individual about an object (company, product or service) which are created in the consumer's mind when they think about a company, its products or services. Image differentiation refers to the way the way the public perceives the company or its products and is affected by many factors beyond the company's control (Bashin, 2016). It is the final impression of the product or company that the customer receives though both his and her physical senses and psychological experience. Image is based on the organisation's dedication, experience, trust, communication, interaction and investment. Organisations with positive image (reputation) enjoy market advantage, which is manifested in sales, profits and relationship with suppliers, government, consumers and other stakeholders (Miletic, 2010).

Image differentiation relates to various distinguishing aspects relating to the image of a company (corporate image) or that of the company's products (brand image). The sum total of the institution's corporate and brand image leads to competitive advantage and ultimately enhance organisation's performance. The development of a strong and distinctive image requires greater creativity and a lot of work (Claessens, 2015) on the part of the institution's management and personnel.

\section{Corporate image}

Corporate image refers to the perception of organisation held in consumer's memory and works as a filter which impacts the perception of the company (Gronroos, 1988). Miletic (2010) defines corporate image as the whole set of perceptions, expectations and values which customers have in relation to a specific organisation. Abd-El-Salam, Shawky and El-Nahas (2013) noted that corporate image is closely related to brand equity. Several authors concur that corporate image is the overall impression; left in the customer's mind, as a result of accumulative feelings, ideas, attitudes and experiences with the organisation, stored in the memory, transformed into positive or negative meaning, retrieved to reconstruct image and recalled when the name of the organisations is heard or brought to one's mind (Abd-El-Salam, et al, 2013). The firm's corporate image is thus a result of the communication process in which the organisation create and spreads a specific message that constitute their strategic intent; mission, vision , goals and identity that reflects their core values that they cherish (as cited in Abd-El-Salam, Shawky and El-Nahas, 2013).

Corporate image constitute of two fundamental elements; the functional component and the emotional component 
Table 1. Atmosphere dimensions

\begin{tabular}{cccc}
\hline Visual Dimension & Aural Dimension & Alfactory dimension & Tactile Dimension \\
\hline Colour & Volume & Scent & Softness \\
Brightness & Pitch & Freshness & Smoothness \\
Size & & & Temperature \\
Shapes & & & \\
\hline
\end{tabular}

Source: Kotler (1974)

(Kandampully and $\mathrm{Hu}$ 2007). The functional component refers to the tangible characteristics that can be measured and evaluated easily (Weiwei, 2007) or tangible elements of perceived quality (Nguyen and Leblanc, 2001) such as corporate name, logo, publications, websites, exhibitions, buildings and physical characteristics (Stamm, 2008; Kandampully and $\mathrm{Hu}, 2007)$. The emotional component of corporate image refers elements such as feelings, attitudes and beliefs that one has towards the organisation (Kandampully and $\mathrm{Hu}$ (2007); Weiwei (2007). These components are consequences from accumulative experiences the customer has with the passage of time with the organisation (Weiwei, 2007). It can be concluded that corporate image is a result of an aggregate process by which consumers compare and contrast the various attributes of an organisation (Weiwei, 2007) such as symbols, events, media, atmosphere (Kotler, 2009). Corporate image is therefore an asset which gives the organisation a chance to differentiate itself, aiming to maximise their market share, profits, attracting new customer and retaining existing ones. It also assists in neutralising threats of competitor actions and leads to success and survival in the market.

Podnar (2015) suggested ways an organisation can achieve corporate image such as; honesty - sharing with public all information that relates to the real attributes of the company by revealing organisational values to conform to the norms, expectation and values of the shareholders. Giving unbiased image of your company. Consistency- identity characteristics should be expressed through time, crating messages through time. Ensuring that identity is authentic. Working towards transparency and revealing all general information about strategic future goals and activities and Vouching for reliability and relevance of information.

\section{Brand image}

A brand image is a set of perceptions, expectations and values which customers have towards a particular product or service. It is the totality of product or service reputation (Miletic, 2010). The brand image plays a vital role in creating customer satisfaction. Customer's perceptions about the product or service characteristics are influenced by their perceptions of the brand or branding. Good brand image not only indicates that the brand has a positive image, but also shows a higher level of brand image strength than other brands. Miletic (2010) notes that brand image attracts customers, and is the main reason why specific relationships are established between customers and the brand image. An institution's reputation (corporate/ brand image) is a firm's intangible source of competitive advantage, which increases while it is transmitted from person to person. This reputation can be conveyed in different ways, including symbols, media, atmosphere and events (Kotler 2009).
- Symbols - Image can be identified by strong symbols or logos. The brand's logo typically serves as a means of resolving the problem of indistinguishability (Park et $\mathrm{al}, 2012$ ) and facilitates the identification of the brand and its differentiations from competing alternatives. As cited in Park et al (2012), logos act as the primary visual representation of the brand's image and meaning and as a result they shape the brand's reputation along with consumer's attitudes and their purchase intentions.

- Atmosphere (Atmospherics) - refers to the physical space occupied by the company. Atmosphere describes the conscious designing of the space to create certain effects in buyers. It is the effort of design buying environments to produce specific emotional effects in the buyer that enhance his/ her purchase probability (Kotler, 1974). Atmosphere is apprehended through sense, using visual, aural, alfactory and tactile dimensions (See Table 1).

- Media-the chosen image must be worked into the advertisements and media that could convey a distinctive story, mood, or claim. Walkersands communications(n.d) explained that the best way to build and nurture an effective brand image is through a multi-disciplinary approach that combines owned, earned and paid media in a coordinated, digital ecosystem constructed of public relations, social media and other elements.. An increasing number of companies and institutions are using social media to for the creation of both corporate and brand image. However, companies could still lose their images quite quickly because consumer response and intercommunication limits the possibilities for the company to control and manage the content of communication (Kunykaite and Pilgrimiene, 2013).

- Events- this can be built through the events the company sponsors. Sponsoring an event is a significant way to create competitor differentiation. The name of the sponsor has the opportunity to stand-out head and shoulders above the competitor (Amaoko et al, 2012). The popularity behind popularity of sponsorship as a marketing tool to achieve image goals is the general assumption that, by linking a brand to an event, the image of the event can be transferred to the image of the sponsor (Novais and Arcodia, 2013).

\section{RESEARCH METHODOLOGY}

This research study employed a descriptive survey design.In this study, quantitative approach was employed. Quantitative research minimises subjectivity or judgement thereby enabling the researcher to generalise the findings over 


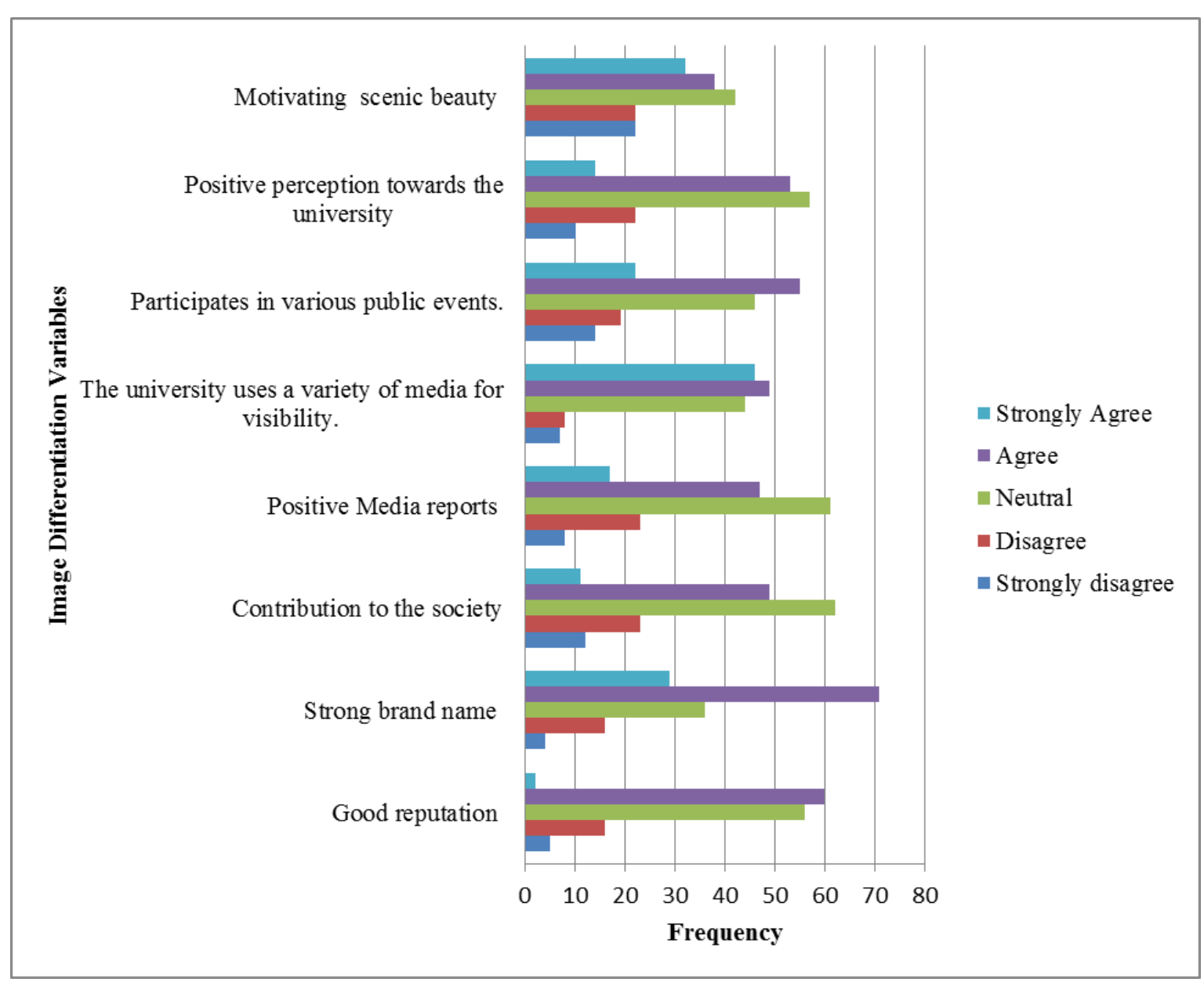

Figure 2. Image Differentiation

Source: Primary Data

a large population, that is, findings can be generalised among other private tertiary education institutions in Botswana. The target population for the study included staff members who are in the management position or heads of department and students of two private universities. In this study, probability -stratified random sampling was used to select respondents from each institution within the stipulated categories. Data was collected through the use of interviewee completed questionnaire using drop-and-pick method of questionnaire administration. Data was analysed using a Statistical Package for Social Sciences (SPSS) version 20.0 software.

\section{DATA FINDINGS}

\section{Image Differentiation and Competitive Advantage in PTEIs}

The following are the results on image differentiations as a means of gaining competitive advantage among private tertiary education institutions. The results indicate the students and management staff's perception on the extent to which they agree or disagree that their institutions employ image differentiation strategy as a means of gaining competitive advantage. Findings inform concerned stakeholders as to what actions must be taken to achieve competitive advantage.

Figure 2 indicates that a similar trend continued to recur as most of the respondents rated their institutions average, based on various image dimensions. Three percent and 60 percent of the respondents agreed and strongly agreed that the university is selected for its good reputation while $10.5 \%$ and $3.2 \%$ disagreed and strongly disagreed respectively. This is a clear indication of the good reputation increase the competitiveness of tertiary education institutions. A strong brand name was also considered to be essential and evident in tertiary education institutions. Twenty eight percent and 71\% of the respondents agree and strongly agree that the university its best strong brand name, However, $15 \%$ and $2.6 \%$ of the respondents disagreed and strongly disagreed respectively to this assertation. Good media reports were rated high by the respondents (48\%) and there is still evidence that not all respondents are happy with media reports pertaining to their institutions (19.8\%). Findings support that image is a product of positive media reports and communication since a large number of respondents attested that their institutions used a variety of media such as websites, social media, television, newspaper advertising to increase visibility. However, these findings differ from Akareem and Hossain (2016), who found that promotional activities tend to lower quality expectations by students. They believe that word of mouth references over sponsored programmes help to create better brand image for the institution. Miletic (2010) found that a company that wants an advantage over competitors on the market has to shape the image of the product / service in a way to run the story about it, and this is achieved by appropriate communication. ibid 
Table 2. Cross tabulations between Image Differentiation, Occupation and Universities

\begin{tabular}{|c|c|c|c|c|c|c|c|c|c|}
\hline \multicolumn{2}{|c|}{$\begin{array}{c}\text { OCCUPATION / } \\
\text { UNIVERSITY }\end{array}$} & \multirow{2}{*}{$\begin{array}{c}\begin{array}{c}\text { Good } \\
\text { reputation }\end{array} \\
4.25\end{array}$} & \multirow{2}{*}{$\begin{array}{c}\text { Strong } \\
\text { Brand } \\
\text { Name }\end{array}$} & \multirow{2}{*}{$\begin{array}{c}\begin{array}{c}\text { University } \\
\text { contributes to } \\
\text { the society }\end{array} \\
3.56\end{array}$} & \multirow{2}{*}{$\begin{array}{c}\begin{array}{c}\text { Positive } \\
\text { media } \\
\text { reports }\end{array} \\
3.63\end{array}$} & \multirow{2}{*}{$\begin{array}{c}\text { Uses } \\
\text { variety of } \\
\text { media to } \\
\text { increase } \\
\text { visibility } \\
4.25 \\
\end{array}$} & \multirow{2}{*}{$\begin{array}{c}\begin{array}{c}\text { Participates in } \\
\text { public events }\end{array} \\
3.81\end{array}$} & \multirow{2}{*}{$\begin{array}{c}\begin{array}{c}\text { Employers } \\
\text { have positive } \\
\text { perception } \\
\text { about } \\
\text { university }\end{array} \\
3.88\end{array}$} & \multirow{2}{*}{$\begin{array}{c}\begin{array}{c}\text { Scenic } \\
\text { beauty } \\
\text { motivate } \\
\text { me }\end{array} \\
4.06\end{array}$} \\
\hline & Mean & & & & & & & & \\
\hline Staff & Std. Deviation & .775 & .619 & .727 & .885 & .775 & .981 & .719 & 1.237 \\
\hline \multirow{2}{*}{ Student } & Mean & 3.38 & 3.59 & 3.11 & 3.23 & 3.72 & 3.28 & 3.18 & 3.14 \\
\hline & Std. Deviation & .931 & .981 & 1.033 & 1.020 & 1.094 & 1.145 & 1.027 & 1.293 \\
\hline \multirow{2}{*}{ Univ. A } & Mean & 3.66 & 3.48 & 3.02 & 3.39 & 3.60 & 2.98 & 3.15 & 3.61 \\
\hline & Std. Deviation & .867 & 1.036 & 1.032 & .936 & 1.196 & 1.133 & 1.062 & 1.282 \\
\hline \multirow{2}{*}{ Univ. B } & Mean & 3.35 & 3.80 & 3.24 & 3.19 & 3.88 & 3.56 & 3.32 & 2.99 \\
\hline & Std. Deviation & .987 & .923 & .997 & 1.055 & .982 & 1.089 & .992 & 1.284 \\
\hline \multirow{2}{*}{ Total } & Mean & 3.47 & 3.67 & 3.15 & 3.27 & 3.77 & 3.33 & 3.25 & 3.23 \\
\hline & Std. Deviation & .951 & .978 & 1.014 & 1.012 & 1.076 & 1.138 & 1.020 & 1.314 \\
\hline
\end{tabular}

Source: Primary Data

(2010) noted that an integrated function of public relations and advertising contributes to the overall image and reputation of the institution and its products. Kotler and Armstrong (2010) support that organisations / institutions can employ promotional activities to create organisational image. Institution's image as perceived by the industry is important since the industry is the receiving end for the university products and services and as a result, there was a good rating by the respondents, with a total of $44 \%$ agreeing and strongly agreeing, while a total of $20.5 \%$ disagreed respectively; that the industry has a positive image towards the institution. The appearance of the institutions is of paramount importance in determining its competitiveness. $28.2 \%$ of the indicated that they were not motivated by the scenic beauty of the university, an indication for the need to improve institutions' scenery. A good reputation may assist a pioneer firm build an innovate image in the industry (Porter, 1985).

Mean scores and standard deviations between the two institutions do not show any major disparities, indicating that there were no major differences in the perceptions among students and among management staff of the two institutions as indicated in Table 2. The total mean scores for image differentiation variables were in the range of 3.15 to 3.77. Most management staff strongly agreed (mean 3.56 to 4.28 ) against students who scored between 3.11 to 3.72 an indication that students do not fully agree that their institutions have good image. Overall, the university's contribution to the society and motivating scenic beauty received the lowest mean score of 3.15 and 3.23 respectively. Respondents from University A rated their institution more positively on scenic beauty (mean 3.61) against 3.23 for University B. These findings confirm Kotler (2009) who noted that image is a combination of elements such as symbols, events, media, atmosphere (Kotler, 2009). Kettunen (2005) found that differentiated education requires good marketing abilities, a reputation for quality and a long tradition and features to attract highly skilled labour, scientists and creative people.

\section{CONCLUSIONS AND RECOMMENDATIONS}

The study sought to analyse image differentiation strategies of Private Tertiary Education Institutions in Botswana may employ in order to gain competitive advantage.
The study revealed that private universities under study have applied image differentiation strategies to some extent, yet it is still evident that they have not done enough to ensure that their institutions stand out from competition as evidenced by a comparative analysis by institution and occupation ( mean scores). The results revealed that image differentiation can be achieved through good reputation, strong brand name and institution's contribution to the society. To achieve competitive advantage, private tertiary education institutions must enhance positive media reports by employing a variety of media to increase visibility, participate in public events to gaining visibility. Other potential avenues for competitive advantage include creation of positive perception towards the institution and enhancing the scenic beauty of the institution. It was recommended that tertiary education administrators should create a strong brand name and positive image to differentiate their institutions for the achievement of competitive advantage. Activities such as improving the scenic beauty of the institutions, community engagement and promotional activities will help increase the visibility of the institutions and hence gain competitive advantage. Use of Brand Ambassadors and reputable spokespersons or endorsers can assist in increasing word -of mouth communication as opposed to use of media which is normally perceived as biased. It was recommended that institutions invest in research resources, technology and facilities to offer practical courses and move away from theory it impacts on the quality of graduates and institution's competitiveness. Quality measures in tertiary institutions encompass quality of infrastructure, quality of staff, quality of students and the research output. Private tertiary education institutions should seek to attract the right caliber of staff, both locally and internationally in order to differentiate themselves and create competitive advantage.

\section{REFERENCES}

Abd-El-Salam, Shawky and El-Nahas (2013). The Impact of Corporate Image and Reputation on Service Quality, Customer Satisfaction and Customer Loyalty Testing the Mediating Role. Case Analysis in an International Service Company. The business Management Review, 3(2), 178-196. 
Akareem, H. S. and Hossain, S. S. (2016) Determinants of Education Quality: What Makes Students' Perception Different? Open Review of Educational Research, 3(1), 52-67. https://doi.org/10.1080/23265507.2016.1155167

Amadeo, K. (2011). What Is Competitive Advantage? 3 Strategies That Work. Available at: https://www.thebalance.com/ what-is-competitive-advantage-3-strategies-that-work3305828

Amaoko, G. K., Junior, S. K., Daetey-Baak, K. and Dzogbenuku, R. K. (2013). The Effect Of Marketing Communication Performance: A case study of Airtel Ghana. African Journal of Marketing Management, 4(2) 65-79. https://doi.org/10.5897/AJMMX11.006

Armstrong, G., Adan, S., Denize, S. and Kotler, P. (2012). Principles of Marketing. $5^{\text {th }}$ Edition. Sydney. Prentice Hall.

Awwad, A. S., Al Khattab, A. A. and Anchor, J. R. (2013). Competitive Priorities and Competitive Advantage in Jordanian Manufacturing. Journal of Service and Management, (6), 69-79. https://doi.org/10.4236/ jssm.2013.61008

Boyd, R. L. (2012). Customer service in Higher Education: Finding the middle ground. The Mentor. An Academic advising Journal, 14. https://doi.org/10.26209/MJ1461308

Durkin, M., Howcroft, B. and Fairless, C. (2016). Product Development in Higher education Marketing. International Journal of Education Management, 30(3), 354-369. https://doi.org/10.1108/IJEM-11-2014-0150

Ernst Young (2011). Higher Education and the Power of Choice. Ernst Young Global Limited. Australia.

Gebauer, H., Gustafsson, A. and Witell, L. (2011). Competitive Advantage through Service Differentiation by Manufacturing Companies. Journal of Business and Research, 64(12), 1270-1280. https://doi.org/10.1016/ j.jbusres.2011.01.015

Hoque, K. E., Razak, A. A. and Zohora, M. F. (2013). Service delivery in higher Education: A Comparative Study between Public and Private Universities. Life science Journal, 10(3), 108-117.

Reimer, D. and Jacob, M. (2010). Differentiation in Higher Education and Its Consequences for Social Inequality: Introduction to Special Issue. Higher Education, 61, 223227. https://doi.org/10.1007/s10734-010-9373-z

Kandampully, J. and Hu, H. H. (2007). Do Hoteliers Need to Manage Image to Retain Loyal Customers? International Journal of contemporary Hospitality management, 19(6), 435443. https://doi.org/10.1108/09596110710775101

Kasule, G. W., Wesselink, R. and Mulder, M. (2014). Developing Innovation Competence Profile for Teaching Staff in Higher Education in Uganda. Journal of Education, (2), 1-26.

Kotler, P. and Armstrong, G. (2010). Principles of Marketing. $13^{\text {th }}$ Global Edition. Upper Saddle River, New Jersey: Pearson Education.

Kunykaite and Piligrimiene (2013). Communication in Social Media for Company's Image Formation. Economic and Management, 18(2), 305-317. Available at: https://doi.org/10.5755/j01.em.18.2.4651
Malik, M. E., Ghafoor, M. M. and Iqbal, H. K. (2012). Impact of Brand, Service Quality and Price on Customer Satisfaction in Pakistan Telecommunication Sector. International Journal of Business and Social science, 3(23), 123-129.

Mateus, M. B. (2017). How to Achieve Competitive Advantage through Operations. Available at: https://www.linkedin. $\mathrm{com} /$ pulse/how-achieve-competitive-advantage-throughoperations-manuel-b-mateus

Milan, R. P., Davies, S. and Zafira, D. (2016). Barriers to Differentiation: Applying Organisational Studies to Ontario Higher education. Canadian Journal of Higher education, 46(1), 19-37.

Miletic, S. (2010). Image Communication and Competitive advantage. Facta Universitatis, Series: Economics and Organization, 7(1), 119-128. Available at: http://facta.junis. ni.ac.rs/eao/eao201001/eao201001-10.pdf

Mixon. P. (2014). Do What You Do Best: Competitive Advantage as A Differentiator in Higher Education. The evolllution. Available at: https://evolllution.com/opinions/bestcompetitive-advantage-differentiator-higher-education/

Nikolas, F. (2016). Competitive Strategies and Industry Analysis. Available at: http:/www.nickols.us/porterbasics.pdf

Novais, M. A and Arcodia, C. (2013). Measuring the Effects of Event Sponsorship: Theoretical Frameworks and Image Transfer Models. Journal of Travel and Tourism Marketing, 30(4), 308-334. https://doi.org/10.1080/10548408.2013. 784149

Owino, E. O. (2013). The Influence of Service Quality and Corporate Image on Customer Satisfaction Among Universities in Kenya (Dissertation/ Thesis). Available at: http://chss.uonbi.ac.ke/sites/default/files/chss/Edward\%2 00wino\%20PhD\%20Thesis.pdf

Park, C. W., Eisingerich, A. B., Pol, G. and Park, J. W. (2013). The Role Of Brand Logos On Firm Performance. Journal of Business Research, 66, 180-187. https://doi.org/10.1016/ j.jbusres.2012.07.011

Podnar, K. (2015). Corporate Communications: A Marketing Viewpoint. 1st Edition. London and New York: Routledge. https://doi.org/10.4324/9781315752785

Porter, M. (1990). The Competitive Advantage of Nations. N.Y., USA: The Free Press. https://doi.org/10.1007/978-1-34911336-1

Porter, M. (1985). Competitive Advantage. N.Y., USA: The Free Press.

Reeves, M. and Deimler, M. (2017). Adaptability: New Competitive Advantage. Health Care and the Pandemic. Available at: https://hbr.org/2011/07/adaptability-thenew-competitive-advantage\#comment-section

Sigalas, C., Pekka-Economou, V. and Georpopoulos, N. B. (2013). Developing a Measure of Competitive Advantage. Journal of Strategy and Management, 6(4), 320-342. https://doi.org/10.1108/JSMA-03-2013-0015

Smith, D. (2013). Differentiation and Diversification In Higher Education: The Case Of Private Faith Based Higher Education in Manitoba. Canadian Journal of Higher education, 43(1), 23-43. 
Stamm, B. V. (2008). Managing Innovation Design And Creativity ( $2^{\text {nd }}$ edition). United Kingdom: John Wiley and Sons.

Steier, F. A. (2003). The Changing Nexus: Tertiary Education Institutions, The market place and the state. Higher Education Quarterly, 57(2), 158-180. https://doi.org/10.1111/1468-2273.00240

Tanwar, R. (2013). Porter Competitive strategies. IOSR Journal of business and Management, 15(1), 11-17. https://doi.org/10.9790/487X-1511117

Mbuya, T. (2017). The Decline And Fall Of Higher Education In Botswana: Quality Assurance Authorities Complicit (part II). Mmegi online. Available at: http://www.mmegi.bw/ index.php?aid=65977 \&dir=2017/january $/ 20$
The Linguist Chair. (November 10, 2016). The state of Botswana Tertiary Education capture. Part One: The definition problem. The Sunday Standard. Available at: https://www.sundaystandard.info/the-state-of-botswanatertiary-education-capture/

Tizhe, T. K (2016). Diversification Management at Tertiary Education Level: A Review. Journal of Education and Practice, 7(4), 110-115.

Zekiri, J. and Nedelea, A. (2011). Strategies for Competitive Advantage. The annals of The Stefan cel Mare" University of Suceava. Fascicle of the Faculty of Economics and Public Administration, 11(2(14)), 63-73. Available at: https://econpapers.repec.org/article/scmausvfe/v_3a11_3a y_3a2011_3ai_3a2(14)_3ap_3a63-73.htm 